\title{
МОДЕЛЮВАННЯ НІЖКИ ЕНДОПРОТЕЗА ТАЗОСТЕГНОВОГО СУГЛОБА ТА ВИЗНАЧЕННЯ ОПТИМАЛЬНОГО ТИПУ ФІКСАЦЇ̈
}

\author{
Беспалова О. Я., доц., к.б.н., с.н.с. \\ e-maile.bespalova25.05@gmail.com \\ Міщенко Ю. С., ORCID 0000-0001-7844-9834 \\ e-mailsokol7romashka@gmail.com \\ Кафедра БМІ, ФБМІ \\ Національний технічний університет України \\ «Київський політехнічний інститут імені Ігоря Сікорського» \\ Київ, Україна
}

\begin{abstract}
Реферат - Ендопротезування кульшового суглоба є широко поширеним способом лікування захворювань опорнорухового апарату. Заміна хворого суглоба на штучний дозволяє усунути або значно зменшити больовий синдром, та відновити рух в суглобі.

У багатьох випадках ненадійність ендопротеза викликана його розхитуванням. Ризик розхитування зростає пропорціийно давності операиії, $і$ в даний час дана проблема не має будь-якого технічного рімення. Згідно біомеханічної гіпотези основною причиною розхитування ендопротеза є неадекватність функціональних напружень, які діють на кістку в системі кістка-імплантат при фізіологічних навантаженнях. Неправильно підібраний матеріал та тип фіксації ніжки, може прискорити розхитування при збільшенні навантажень на неї.

В роботі проведено дослідження навантажень на ніжку тазостегнового ендопротеза, в залежності від ваги пацієнта та типу фіксаиї імплантату в кістковій тканині. Дослідження було проведено на моделі титанової ніжки, створеної у nросторі SolidWorks.

Показано щзо існує відмінність у перерозподілі навантаження на стегнову компоненту протеза при різних типах фіксачії ніжки для пацієнтів з різною вагою.

В результаті дослідження було встановлено, щзо при дистальній фіксаиії навантаження на протез зростає більш стрімко, та має більше значення ніж при проксимальній фіксачії, що може стати причиною швидшого розхитування ніжки.

Ключові слова - ендопротез, тазостегновий суглоб, проксимальний тип фіксаиії, дистальний тип фіксаиїі, моделювання кульшового суглоба, матеріали для протезування, вагове навантаження на тазостегновий ендопротез.
\end{abstract}

\section{I. Ветуп}

Ендопротезування кульшового суглоба є широко поширеним способом лікування захворювань опорно-рухового апарату. Заміна хворого суглоба на штучний дозволяє усунути або значно зменшити больовий синдром, та відновити рух в суглобі.

У багатьох випадках ненадійність ендопротеза викликана його розхитуванням. Ризик розхитування зростає залежно від давності операції, віку, стану кісткової тканини та виду діяльності пацієнта, і в даний час дана проблема не має будь-якого технічного рішення.

3 недавніх пір дедалі активніше використовується безцементне ендопротезування, адже воно являється більш перспективним у випадках заміни протеза. Це дає змогу проводити такі операції пацієнтам молодшого віку. Але чим молодший пацієнт, тим складніше спрогнозувати розвиток його організму. За 10-20 років, людина 3 обмеженою руховою активністю може значно збільшити свою вагу. Збільшення маси може призвести до збільшення навантаження на імплантат i, як наслідок, прискореного розхитування та передчасного ревізійного втручання.

Згідно біомеханічної гіпотези основною причиною розхитування ендопротеза $є$ неадекватність функціональних напружень, які діють на кістку в системі кістка-імплантат при фізіологічних навантаженнях [1].

Неправильно підібраний матеріал та тип фіксації ніжки, може прискорити розхитування при збільшенні навантажень на неї.

Метою роботи було виявлення оптимального типу фіксації протеза, при якому ніжка піддається найменшій деформації при збільшенні навантаження на неї.

\section{II. Типи фіксації ніжки тазостегнового ендопротеза}

Існує два типи фіксації кульшового суглоба в кістці - цементний та безцементний. Різниця між ними полягає в тому, що цементні ніжки кріпляться в кісткову тканину за допомогою 
спеціального полімерного цементу, а безцементні ніжки кріпляться шляхом щільної посадки. Їх вбивають в кістку, канал якої спеціальними рашпілями підганяють під форму ніжки протеза. [2].

Поверхня безцементної ніжки має шорстке напилення (часто використовують гідроксиапатит), яке дозволяє кістці вростати в протез. На основі цього безцементні ніжки також поділяються за типом фіксації [3].

Для максимальної стабілізації існують два принципово різних способи кріплення ніжки безцементної фіксації.

Перший з них передбачає стабілізацію протеза шляхом фіксації дистальної частини ніжки в діафізарній частині стегнової кістки. Це досягається тим, що дистальний відділ протеза покритий пористою речовиною, та має циліндричну форму [4].

Під час введення протеза пористе покриття ніжки щільно втискається в кортикальні стінки, забезпечуючи таким чином ротаційну стабільність і перешкоджаючи зсувам, що виникають при осьовому навантаженні. Цей спосіб фіксації ніжки називається діафізарним або дистальним [5].

При другому способі фіксації протеза ніжку первинно стабілізують в метафізарний частині стегнової кістки. В цьому випадку фіксація досягається щільним впровадженням ендопротеза в губчасту кісткову тканину [6].

На відміну від дистальної фіксації, стабільність імплантату в метафізарний частини стегнової кістки залежить не стільки від покриття ніжки, скільки від геометрії протеза і його відповідності формі проксимального відділу стегнової кістки $[5,6]$.

\section{III. Навантаження та осідання ніжки тазостегнового протеза}

Безліч чинників визначають ступінь рухливості ніжки ендопротеза в порожнині стегнової кістки при фізіологічному навантаженні. Анатомо-фізіологічні особливості пацієнта включають геометрію ендостального відділу стегнової кістки, якісні характеристики губчастої кісткової тканини (остеопороз, остеосклероз) і кортикальних стінок (товщина і форма), вагу, ріст і життєву активність [7].

Для того щоб протез безцементної фіксації забезпечував безболісне навантаження на ногу при максимальній амплітуді рухів, необхідна майже повна відсутність рухливості між імплантатом і кістковою тканиною. Проте, в типових випадках в найближчому післяопераційному періоді спостерігається найбільше осідання протеза, яке прогресивно зменшується в міру збільшення навантажень і фіксації ніжки в кістці [8].

Після закінчення періоду, необхідного для утворення кісткового зрощення (зазвичай це настає через 2,5-3 місяці) пацієнт повертається до нормальної ходьби. При цьому взаємодія металу і кісткової тканини має вигляд пружної еластичної деформації і визначається як мікрорухливість [8].

Складні радіометричні дослідження показали, що практично будь-який протез має зсув відносно стегнової кістки під час фізіологічного навантаження на кінцівку. Зазвичай ця рухливість носить коливальний характер, і положення імплантату відновлюється під час неопорної фази кроку. Однак при надлишкових навантаженнях, остеопорозі, погрішності хірургічної техніки зміщення перевищують допустимі значення і призводять до значного осідання ніжки протеза [8].

Найбільш вірогідною ознакою щільності первинної посадки ніжки є ротаційна стабільність протеза. Стійкість безцементної ніжки до ротаційних зміщень визначається, перш за все, відстанню між крайніми точками контакту протеза 3 кісткою і віссю ротації імплантату, яка може бути представлена як поздовжня вісь кістковомозкового каналу. Таким чином, контакт між кісткою і внутрішньою поверхнею протеза на рівні остеотомії шийки стегнової кістки значно зменшить ротаційну мікрорухливість, особливо якщо при цьому протез контактує з передньою і задньою кістковими стінками [8].

Виходячи 3 цих положень, більш висока остеотомія шийки стегнової кістки призведе до зменшення ротаційного навантаження на протез за рахунок зміни розташування протеза в кістці, який буде зміщений більш медіально. Зсув рівня остеотомії проксимально на 10 мм призводить до зменшення ротаційної рухливості на $45 \%$ [8].

Величина мікрорухливості між імплантатом і кісткою визначається просторовим розподілом точок контактів між ними і коефіцієнтом тертя на кордоні кістка - метал. Як правило, розхитування ніжки починається 3 появи над- 
лишкових ротаційних рухів імплантату в каналі, що призводить в подальшому до ретроверсії протеза. Нерідко ротаційна нестабільність поєднується з міграцією протеза в кістці, яка призводить до вкорочення кінцівки і може викликати нестійкість (підвивихи) суглоба [8].

\section{IV. Вибір матеріалу}

Матеріал, з якого робиться ніжка ендопротеза кульшового суглоба, з одного боку повинен бути досить міцним, щоб не зламатися, 3 іншого боку - еластичним, тобто здатним деформуватися при навантаженні (для ніжок безцементної фіксації модуль пружності повинен бути максимально можливо близьким до модуля пружності самої кістки), а 3 третього боку матеріал повинен бути інертним, та добре зростатися 3 кісткою (цей параметр важливий для безцементних ніжок) $[8,10]$.

Для виготовлення безцементних стегнових компонентів ендопротеза найбільш часто використовуються кобальт-хромові і титанові сплави. Сплави титану мають кращу біологічну сумісність, але остеоінтеграція можлива при використанні і того, і іншого матеріалу. Оскільки головним фактором довгострокового ефективного функціонування пристрою $\epsilon$ передача напруги, дуже велике значення має модуль пружності матеріалу. Модуль пружності титану ближче до модуля пружності кістки і приблизно вдвічі менше, ніж у кобальт-хрому $[8,9]$.

Істотним недоліком титану $\epsilon$ виражене ослаблення його міцності при наявності нерівностей на поверхні [8].

Окрема проблема - потенційна токсичність матеріалу. Іони кобальту і хрому виявляються в невеликих концентраціях в рідинах і тканинах організму, але, навіть в малих дозах, вони можуть володіти цитотоксичною дією. 3 іншого боку, титан асоціюється 3 формуванням більшої кількості продуктів зносу і виділенням іонів, але краще переноситься на клітинному рівні [8].

В ході аналізу матеріалів, було обрано матеріал для моделювання - титановий сплав ti-3al-8v-6cr-4mo-4zr (ss) [9, 11].

\section{V. Дослідження впливу зміни ваги тіла на ніжку ендопротеза в залежності від типу його фіксації}

Вага, яка впливає на один суглоб дорівнює половині різниці маси тіла та нижніх кінцівок людини [12].
Маса нижньої кінцівки становить приблизно 20 \% від всієї маси тіла людини [13].

Отже маємо, що при вазі людини 40 (кг) навантаження на ніжку буде $120(\mathrm{H})$, а для людини в 100 (кг) - $300(\mathrm{H})$.

1. Навантаження на ніжку ендопротеза, при вазі людини 40 кг:

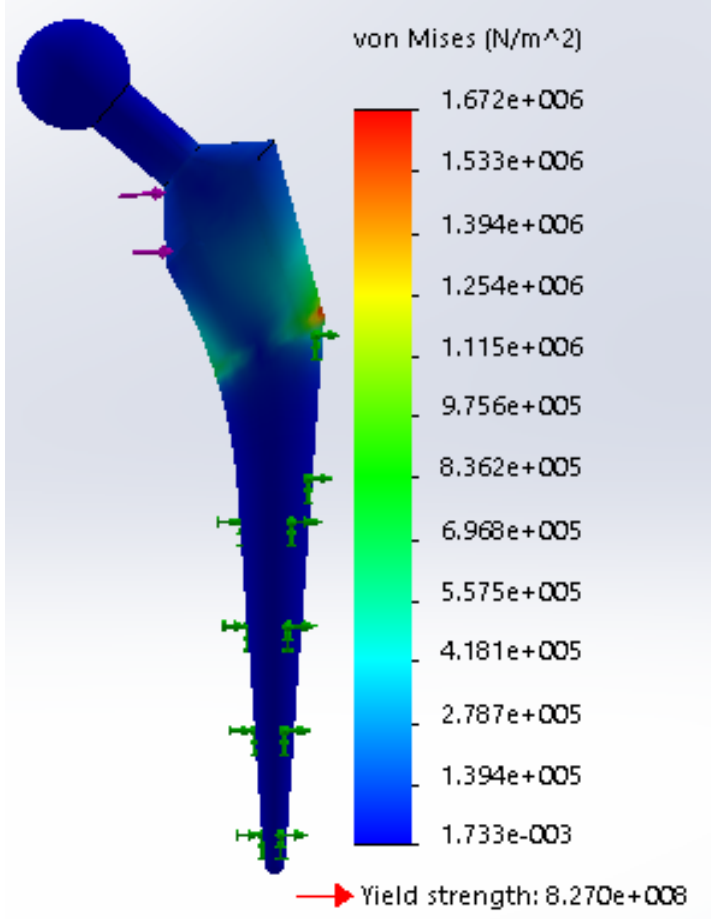

Puc. 1. Модель навантаження на ніжку, при вазі людини 40 кг, дистальне кріплення

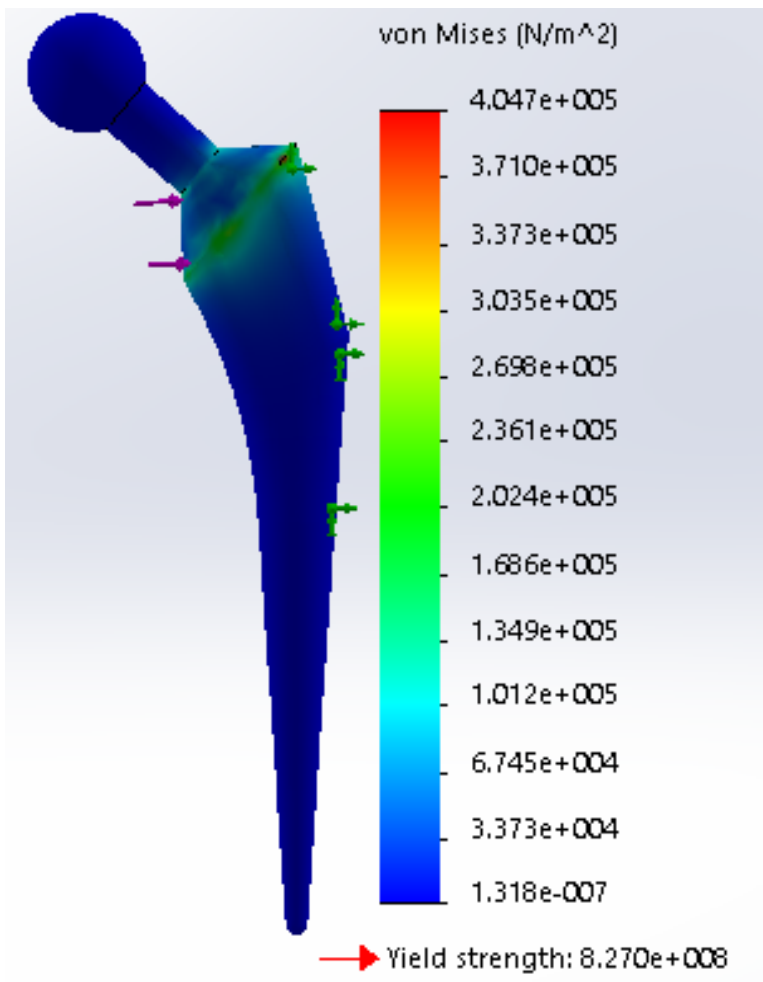

Puc. 2. Модель навантаження на ніжку, при вазі 100 кг, дистальне кріплення 
2. Навантаження на ніжку ендопротеза, при вазі людини 100 кг:

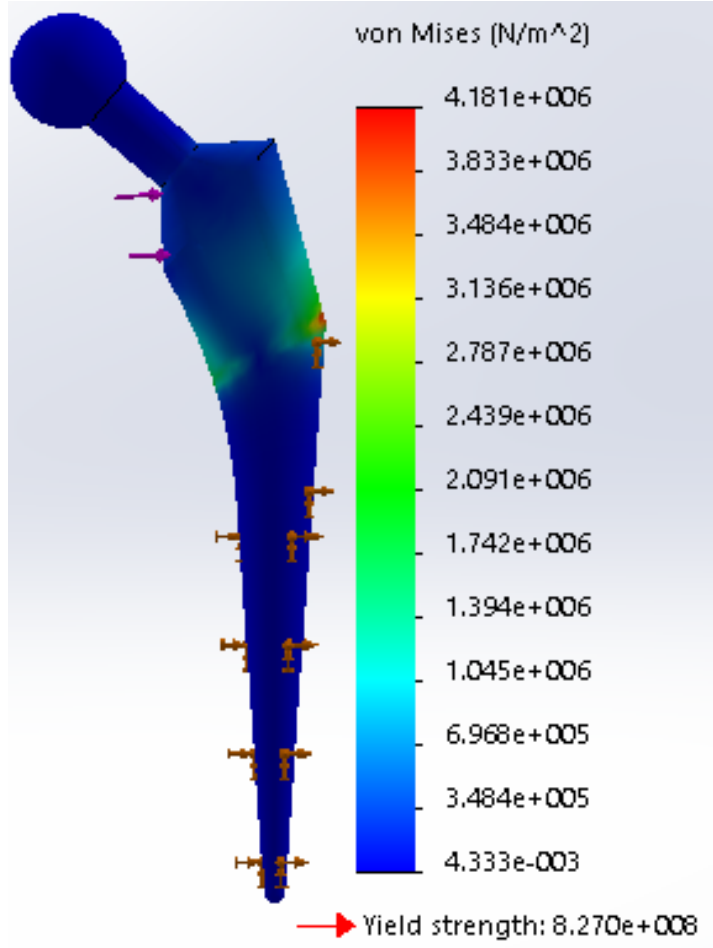

Puc. 3. Модель навантаження на ніжку, при вазі людини 100 кг, дистальне кріплення

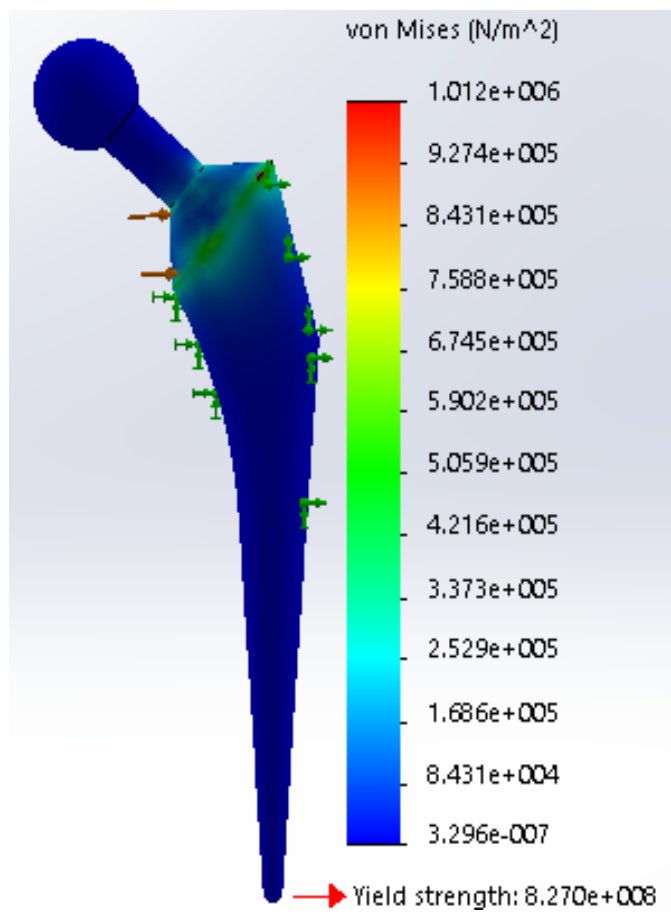

Puc. 4. Модель навантаження на ніжку, при вазі людини 100 кг, проксимальне кріплення

\section{VI. Висновки}

В роботі було визначено та охарактеризовано типи фіксації ніжки, в залежності від типу проксимального каналу стегнової кістки. Проаналізовано випадки використання різних типів фіксації.

Вибрано матеріал - сплав титану, так як йо- го модуль пружності близький до модуля пружності кістки і він являється найбільш біосумісним матеріалом.

Отримано модель, у середовищі SolidWorks.

При дослідженні моделі, було встановлено, що при дистальній фіксації навантаження на протез зростає більш стрімко, та має більше значення ніж при проксимальній фіксації, що може стати причиною швидшого розхитування ніжки.

\section{ПЕРЕЛІК ПОСИЛАНЬ}

[1] Значення розподілу напруг в кістковій тканині навколо компонентів ендопротеза тазостегнового суглоба для стабільної фіксації імпланта / [М. А. Корж, О. В. Танькут, В. А. Філліпенко та ін.]. // Вісник СевНТУ: зб. наук. пр.. №137. - C. 110-118.

[2] Тихолов Р. М. Стегнові компоненти ендопротеза цементної фіксації [Електронний ресурс] / Р. М. Тихолов, В. М. Шаповалов // РНИИТО им. Р.Р. Вредена. - 2017. Режим доступу до ресурсу: http://medbe.ru /materials/ /endoprotezirovanie /bedrennye-komponenty-endoprotezatsementnoy-fiksatsii

[3] Эндопротезирование тазобедренного сустава: отзывы пациентов о реабилитации [Електронний ресурс] - Режим доступу до ресусу: http://sustav.info/lechim/hirurg/endoprotezirovanie-tazobedrennogo-sustava-otzyvy.html.

[4] Середа А. П. Який ендопротез кульшового суглоба найкращий? Як вибрати ендопротез кульшового суглоба? [Електронний ресурс] / А. П. Середа // Сайт клиники травматологии и ортопеди Первого МГМУ им. И. М. Сеченова. - 2014. - Режим доступу до ресурсу: http://travmaorto.ru/264.html.

[5] Как устроен эндопротез? [Електронний ресурс]. - 2016. Режим доступу до ресурсу: https://med.vesti.ru/ /articles/zabolevaniya/kak-ustroen-endoprotez/.

[6] Ендопротезування кульшового суглоба [Електронний pecypc]. - 2017. - Режим доступу до ресурсу: http:// //ortoped.sumy.ua/ru/endoprotezuvannya-kulshovogo-sugloba/.

[7] Тихолов Р. М. Дизайн бедренного компонента ендопротеза безцементної фіксації [Електронний ресурс] / Р. М. Тихолов, В. М. Шаповалов. - 2017. - Режим доступу до ресурсу: http://bone-surgery.ru/view/dizajn_bedrennogo_komponenta_endoproteza_bescementnoj_fiksacii.

[8] Эндопротез тазобедренного сустава индивидуальный підбор модели и материала для пациента [Електронний pecypc]. - 2018. - Режим доступу до ресурсу: https:// //ortoped-klinik.com/orthopedic-services/osteoarthritis-of-thehip/modeli-endoprotezov-tazobedrennogo-sustava.html.

[10] Шипша В. Г. Титанові сплави [Електронний ресурс] / /B. Г. Шипша - Режим доступу до ресурсу: http:// //www.naukaspb.ru/spravochniki/Demo\%20Metall/3_17.htm.

[11] Костное ремоделирование [Електронний ресурс]- Режим доступу до ресурсу: http://surgeryzone.net/info/infotravmatologia/kostnoe-remodelirovanie.html.

[12] Различия бесцементного и цементного эндопротезирования тазобедренного сустава [Електронний ресурс] - Peжим доступу до ресурсу: http://msk-artusmed.ru/razlichiyabestsementnogo-i-tsementnogo-endoprotezirovaniyatazobedrennogo-sustava/.

[13] Тихолов Р. М. Биомеханика тазобедренного сустава [Електронний ресурс] / Р. М. Тихолов, В. М. Шаповалов // РНИИТО им. Р.Р. Вредена. - 2018. - Режим доступу до pecypcy: http://bone-surgery.ru/view/biomehanika_tazobedrennogo sustava.

[14] Дутчак Ю. В. Біомеханіка / Ю. В. Дутчак. - Хмельницький, 2013. - 19 с. 


\title{
МОДЕЛИРОВАНИЕ НОЖКИ ЭНДОПРОТЕЗА ТАЗОБЕДРЕННОГО СУСТАВА И ОПРЕДЕЛЕНИЕ ОПТИМАЛЬНОГО ТИПА ФИКСАЦИИ
}

\author{
Беспалова Е. Я., доц., к.б.н., с.н.с. \\ e-maile.bespalova25.05@gmail.com \\ Мищенко Ю.С., ORCID 0000-0001-7844-9834 \\ e-mailsokol7romashka@gmail.com, Кафедра БМИ, ФБМИ \\ Национальный технический університет Украины \\ «Киевский политехнический інститут шимени Игоря Сикорского», Киев, Украина
}

\begin{abstract}
Pеферат - Эндопротезирование тазобедренного сустава является широко распространеннылм способом лечения заболеваний опорно-двигательного аппарата. Замена больного сустава на искусственньй позволяет устранить или значительно уменьшить болевой синдром, и восстановить движение в суставе.

Во многих случаях ненадежность эндопротеза вызвана его расшатыванием. Риск расшатывания растет пропориионально давности операции, и в настоящее время данная проблема не имеет никакого технического решения. Согласно биомеханической гипотезы основной причиной расшатывания эндопротеза является неадекватность функциональных напряжений, действующих на кость в системе кость-имплантат при физиологических нагрузках. Неправильно подобранный материал и тип фиксации ножки, может ускорить расшатывание при увеличении нагрузок на нее.

В работе проведено исследование нагрузок на ножку тазобедренного эндопротеза, в зависимости от веса пациента и типа фиксации имплантата в костной ткани. Исследование было проведено на модели титановой ножки, созданной в пространстве SolidWorks.

Показано что существует различие в перераспределении нагрузки на бедренную компоненту протеза при различных типах фиксации ножки для пациентов с разным весом.

В результате исследования было установлено, что при дистальной фиксации нагрузки на протез растет более стремительно, и имеет большее значение, чем при проксимальной фиксации, что может стать причиной быстрого расшатывания ножки.

Ключевые слова: Эндопротез, тазобедренный сустав, проксимальный тип фиксаиии, дистальный тип фиксации, моделирование тазобедренного сустава, материаль для эндопротезирования, весовая нагрузка на тазобедренный эндопротез.
\end{abstract}

UDC. 620.17:616.71-001.5-089

\section{MODELING OF THE HIP JOINT LEG AND DETERMINING THE OPTIMAL FIXATION TYPE}

Bespalova O. Ya., doc, c.b.s. e-maile.bespalova25.05@gmail.com

MischenkoYu. S., ORCID 0000-0001-7844-9834 e-mailsokol7romashka@gmail.com, Department of BMI, FBMI National Technical University of Ukraine «Igor Sikorsky Kiev Polytechnic Institute», Kyiv, Ukraine

\footnotetext{
Annotation - Endoprosthetics of the hip joint is a widespread method of treating diseases of the musculoskeletal system. Replacing the patient's joint with the artificial allows to eliminate or significantly reduce the pain syndrome, and restore joint movement.

In many cases, the unreliability of the endoprosthesis is due to its loosening. The risk of loosening increases in proportion to the limitation of the operation, and at present, this problem does not have any technical solution. According to the biomechanical hypothesis, the main reason for loosening the endoprosthesis is the inadequacy of functional stresses acting on the bone in the bone-implant system under physiological stresses. Incorrectly selected material and type of leg fixation, can accelerate lacing with increasing loads on it.

In this work, a study of loads on the leg of the pelvic endoprosthesis, depending on the patient's weight and type of implant fixation in the bone tissue, was performed. The research was conducted on a model of the titanium leg created in SolidWorks space.

It is shown that there is a difference in the redistribution of the load on the femoral component of the prosthesis with different types of leg fixation for patients with different weights.

As a result of the study, it was found that, with distal fixation, the load on the prosthesis increases more rapidly, but it is more important than the proximal fixation, which can cause a faster break in the leg.

Key words: endoprosthesis, hip joint, proximal fixation type, distal type of fixation, hip joint modeling, materials for endoprosthetics, weight load on hip prost.
} 